\title{
RECOVERY OF SPERMATOGENESIS IN PATIENTS WITH LYMPHOMA AFTER TREATMENT WITH CHLORAMBUCIL
}

\author{
S. CHEVIAKOFF, J. C. CALAMERA, M. MORGENFELD* \\ AND R. E. MANCINI \\ Centro de Investigaciones en Reproducción, Facultad de Medicina, \\ Universidad de Buenos Aires, and ${ }^{*}$ Instituto Municipal de Hematologia, \\ Hospital Ramos Mejia, Buenos Aires, Argentina
}

(Received 30th October 1972)

Several publications have pointed out the deleterious action exerted by cytostatic drugs on human spermatogenesis (Heller, Flegeolli \& Watson, 1963; Richter, Calamera, Morgenfeld, Kierszenbaum, Lavieri \& Mancini, 1970; Fairley, Barrié \& Johnson, 1972). As many of the patients who receive cytostatic drugs often have a normal life expectancy, it was considered of interest to study the reappearance of spermatogenesis during variable periods of time after withdrawal of treatment. Van Thiel, Sherins, Myers \& De Vita (1972) pointed out that in a group of such men in remission for 1 to 5 years after treatment with different drugs, persistent azoospermia was present in five out of seven of the treated individuals.

This report concerns observations on a group of five patients with lymphoma who recovered spermatogenesis either partially or totally after treatment with Chlorambucil was suspended. The average age of the patients was 26 years. The daily dose of Chlorambucil was 2 to $10 \mathrm{mg}$, and the total accumulated dose is shown in Table 1. The effect of treatment was assessed by examination of ejaculates which were provided by masturbation following a period of 4 to 6 days abstinence. Macro- and microscopic studies were performed within $1 \mathrm{hr}$ of the specimen being obtained. The volume, turbidity, viscosity, $\mathrm{pH}$, sperm concentration $\left(\times 10^{6} / \mathrm{ml}\right)$, motility and percentage of abnormal cells were recorded in each case.

It can be seen from Table 1 that the five patients received a total dose of Chlorambucil which varied from 410 to $2600 \mathrm{mg}$. After withdrawal of treatment, all patients except Patient 5 developed azoospermia. In this patient, only a severe oligospermia was detected. Patient 3 continued treatment with $10 \mathrm{mg}$ Vinblastine every 5 weeks.

In the case of Patients 1,2 and 5, spermatogenesis may be regarded as having been completely recovered. The wife of Patient 1 became pregnant and the sperm counts of Patients 2 and 5 were within normal values. Patients 3 and 4 only partially recovered their sperm counts, but after a longer observation period, we would have expected to record normal sperm counts. All patients, except Patient 4, had normal sperm counts or were of proven fertility before the initiation of treatment (Richter et al., 1970). Considering the results of 
previous studies and sperm-count recovery in the majority of patients after withdrawal of treatment, it seems probable that Chlorambucil was the cause of azoospermia in Patient 4. Recovery of spermatogenesis began 3 months after withdrawal of the drug in Patient 5 and 24 months after withdrawal in Patient 1. In the remaining patients, recovery was detected after 34 to 58 months but may have started before the checking period.

Although the number of patients is small, it appears that the accumulated dose of the drug is related to the time that recovery of spermatogenesis takes

Table 1. The effect of treatment with Chlorambucil on ejaculate characteristics of five men with lymphoma

\begin{tabular}{|c|c|c|c|c|c|c|}
\hline $\begin{array}{l}\text { Patient } \\
\text { no. }\end{array}$ & $\begin{array}{l}\text { Total dose } \\
\quad(m g)\end{array}$ & $\begin{array}{l}\text { Months after } \\
\text { withdrawal of } \\
\text { treatment }\end{array}$ & $\begin{array}{l}\text { Semen } \\
\text { volume } \\
(m l)\end{array}$ & $\begin{array}{l}\text { Number of } \\
\text { spermatozoa } \\
\left(\times 10^{6} / \mathrm{ml}\right)\end{array}$ & $\begin{array}{c}\text { Motile } \\
\text { spermatozoa } \\
(\%)\end{array}$ & $\begin{array}{c}\text { Abnormal } \\
\text { forms of } \\
\text { spermatozoa } \\
(\%)\end{array}$ \\
\hline 1 & 1450 & $\begin{array}{l}13 \\
24 \\
42\end{array}$ & $\begin{array}{l}5 \\
6 \\
9\end{array}$ & $\begin{array}{c}\text { Azoospermia } \\
\text { l/h.p.f.* } \\
15\end{array}$ & 50 & 8 \\
\hline 2 & 659 & $\begin{array}{r}3 \\
2 \\
2 \\
6 \\
34 \\
35 \\
58\end{array}$ & $\begin{array}{l}4 \cdot 5 \\
4 \cdot 3 \\
4 \\
3 \\
5 \\
5 \\
3 \cdot 4\end{array}$ & $\begin{array}{c}7 \cdot 2 \\
2 \cdot 4 \\
\text { 1/h.p.f.* } \\
\text { Azoospermia } \\
57 \\
25 \\
42\end{array}$ & $\begin{array}{l}36 \\
20 \\
\\
65 \\
60 \\
70\end{array}$ & $\begin{array}{l}14 \\
19 \\
\\
22 \\
18 \\
14\end{array}$ \\
\hline 3 & 2200 & $\begin{array}{r}4 \\
38 \\
42\end{array}$ & $\begin{array}{l}1 \cdot 5 \\
3 \cdot 6 \\
3 \cdot 6\end{array}$ & $\begin{array}{c}\text { Azoospermia } \\
14 \\
10\end{array}$ & $\begin{array}{l}60 \\
60\end{array}$ & $\begin{array}{l}16 \\
16\end{array}$ \\
\hline 4 & 2600 & $\begin{array}{r}1 \\
1 \\
2 \\
58\end{array}$ & $\begin{array}{l}5 \cdot 5 \\
5 \cdot 3 \\
5 \cdot 2 \\
5\end{array}$ & $\begin{array}{c}\text { Azoospermia } \\
\text { Azoospermia } \\
\text { Azoospermia } \\
6\end{array}$ & 10 & 20 \\
\hline 5 & 410 & $\begin{array}{l}1 \\
1 \cdot 5 \\
3 \cdot 5 \\
33 \\
42\end{array}$ & $\begin{array}{l}3 \cdot 8 \\
3 \cdot 5 \\
3 \\
2 \cdot 7 \\
3 \cdot 4\end{array}$ & $\begin{array}{l}4 \cdot 8 \\
0 \cdot 5 \\
5 \\
76 \\
68\end{array}$ & $\begin{array}{l}80 \\
60 \\
30 \\
70 \\
70\end{array}$ & $\begin{array}{l}18 \\
21 \\
22 \\
20 \\
18\end{array}$ \\
\hline
\end{tabular}

* 1/h.p.f. = 1 spermatozoon per high-power field.

place. If Patient 2 who received a total of $659 \mathrm{mg}$ Chlorambucil is compared with Patient 4 who received $2600 \mathrm{mg}$, it will be seen that the first patient had a sperm count of $57 \times 10^{6}$ spermatozoa/ml at 34 months after withdrawal of treatment, while the second patient had only $6 \times 10^{6}$ spermatozoa $/ \mathrm{ml}$ after 58 months of suspension of treatment. On the other hand, the volume of the ejaculate did not vary significantly with treatment, nor was there an increase in the percentage of abnormal sperm forms. Patient No. 1 recovered spermatogenesis and presumably fertilization capacity as. well, since his wife became pregnant. As the pregnancy ended in provoked abortion at 2 months, it was not possible to verify the normality of the fetus. More studies are needed in this field of work, since it is known that some cytostatic drugs have been associated with mutagenic, carcinogenic and teratogenic actions in animals (Gomes, 1970). 
This work was supported by a grant from The Population Council, Inc., New York.

\section{REFERENCES}

Fatrley, K. F., Barrie, J. M. \& Johnson, W. (1972) Sterility and testicular atrophy related to cyclophosphamide therapy. Lancet, ii, 568.

Gomes, W. R. (1970) Chemical agents affecting testicular function and male fertility. In: The Testis, Vol. 3, p. 483. Ed. A. D. Johnson. Academic Press, New York and London.

Heller, C. G., Flegeolli, B. Y. \& Watson, L. J. (1963) Histopathology of the human testis as affected by bis (dichloroacetyl) diamines. Exp. $\mathbb{O}$ Molec. Path. Suppl. 2, 107.

Richter, P., Galamera, J. G., Morgenfeld, M. C., Kierszenbaum, A. L., Lavieri, J. G. \& Mancini, R. E. (1970) Effect of Chlorambucil on spermatogenesis in the human with malignant lymphoma. Cancer, N.Y. 25, 1026.

Van Thiel, D. H., Sherins, R. J., Myers, G. H. \& De Vita, V. T., JR (1972) Evidence for a specific seminiferous tubular factor affecting FSH secretion in follicle-stimulating hormone. $\mathcal{F}$. clin. Invest. 51, 1009. 